\title{
ESTIMATION OF THE DURATION OF SPERMATOGENESIS IN JAPANESE QUAIL, COTURNIX COTURNIX JAPONICA, USING ANTISPERMATOGONIAL CHEMICALS
}

\author{
PAMELA JONES AND H. JACKSON \\ Unit of Reproductive Pharmacology, University of Manchester, \\ Manchester M13 9PL
}

(Received 15th May 1972, accepted 26th Fune 1972)

A recent publication has demonstrated the usefulness of Japanese quail in the detailed investigation of male antifertility chemicals (Jones, Kominkova \& Jackson, 1972). The present study describes the effect on quail fertility of various dose levels of two compounds, busulphan (Myleran) and cyclohexane1,4-diol dimethanesulphonate. Because of the established antispermatogonial actions of these substances in the rat, it was anticipated that an estimate of the duration of spermatogenesis in the avian species would emerge from the present work.

The fertility procedure adopted for these experiments has recently been described (Jones et al., 1972). Myleran, suspended in arachis oil, was administered to groups of four male birds as a single intraperitoneal dose or daily for 5 consecutive days. Cyclohexane-1,4-diol dimethanesulphonate (Jackson, 1971) was administered orally on 5 consecutive days in the same vehicle. Following the procedure described (Jones et al., 1972), eggs were collected daily from each group of mated birds (two females per male) and incubated. The fertility of the males was assessed from the results of opening the eggs on Days 7 and 15.

For both compounds, consistent effects occurred on the fertility pattern, varying in intensity according to the dose used. After single doses of Myleran $(40,30$ or $20 \mathrm{mg} / \mathrm{kg}$ intraperitoneally), the fertility of the males declined to about $30 \%$ of the control value between Day 4 and Day 7 after treatment, followed by a rapid rise to levels approaching or equal to those of controls. This initial decrease was probably due to a functional sterilizing action upon spermatozoa or spermatids (Jackson, 1964). A second antifertility effect later developed with the region of minimal fertility between Days 25 and 27 (Text-fig. 1).

Following the administration of five daily doses of the compound, a similar biphasic pattern of egg fertility occurred, the higher dose level $(5 \times 10 \mathrm{mg} / \mathrm{kg})$ leading to sterility of the eggs collected on Days 26 to 28 inclusive (Table 1). At autopsy, the testes of male birds similarly treated were of minimal size during Weeks 2 and 3 after the two higher single treatments with Myleran and in Week 3 after five daily doses $(10 \mathrm{mg} / \mathrm{kg})$, although spermatozoa were still seen in seminal smears from some males. 


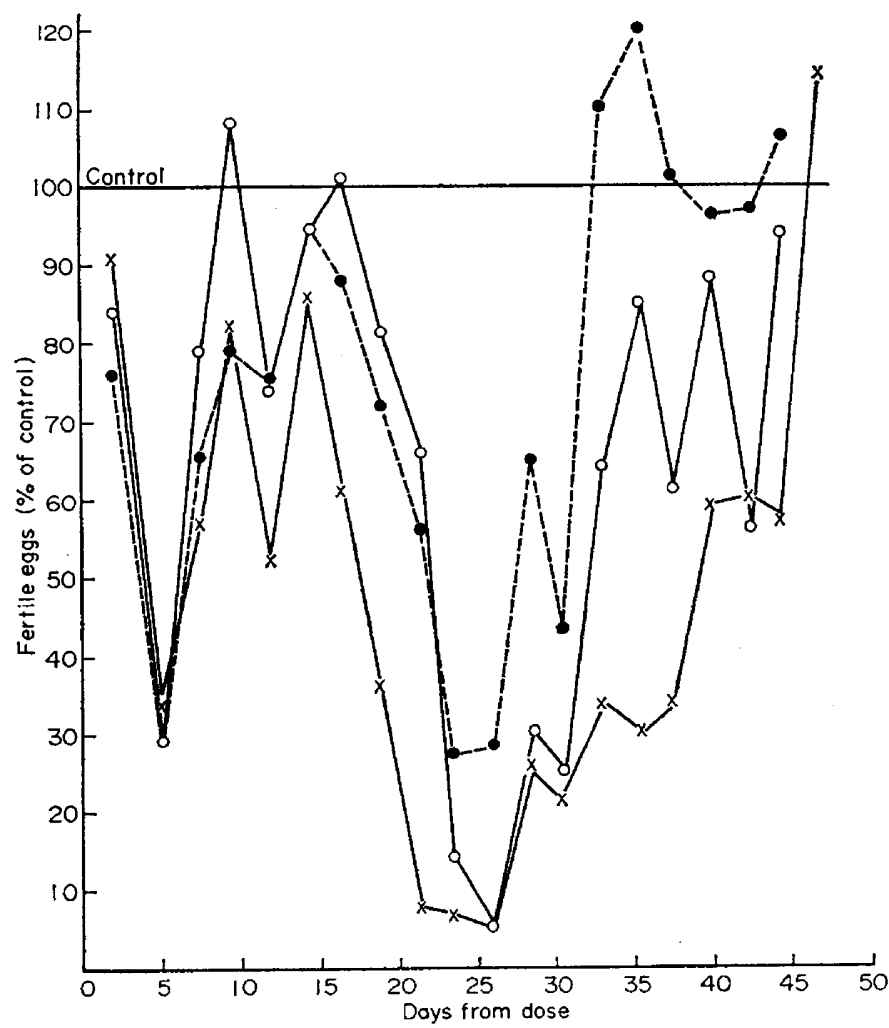

TEXT-FIG. 1. Effect on egg fertility of single intraperitoneal doses of Myleran to male Japanese quail (four birds per dose level) : $\times, 40 \mathrm{mg} / \mathrm{kg} ; 0,30 \mathrm{mg} / \mathrm{kg} ; \bullet, 20 \mathrm{mg} / \mathrm{kg}$.

TABLE 1

ANTISPERMATOGONIAL EFFEGT OF SULPHONIC ESTERS IN JAPANESE QUAIL MANIFEST BY EGG-INFERTILITY

\begin{tabular}{|c|c|c|c|c|c|c|c|c|c|c|c|c|c|c|c|c|c|}
\hline \multirow[b]{2}{*}{$\begin{array}{l}\text { Compound and } \\
\text { dose* (mg/kg) }\end{array}$} & \multicolumn{17}{|c|}{ Percentage of fertile eggs (Controls $=100 \%)$} \\
\hline & $\begin{array}{l}1 \\
\text { to } \\
2\end{array}$ & $\begin{array}{c}3 \\
\text { to } \\
4\end{array}$ & $\begin{array}{l}5 \\
\text { to } \\
7\end{array}$ & $\begin{array}{l}8 \\
\text { to } \\
9\end{array}$ & $\begin{array}{l}10 \\
\text { to } \\
11\end{array}$ & $\begin{array}{l}12 \\
\text { to } \\
14\end{array}$ & $\begin{array}{l}15 \\
15 \\
\text { to } \\
16\end{array}$ & $\begin{array}{c}\text { Days } f \\
17 \\
\text { to } \\
18\end{array}$ & $\begin{array}{c}\text { rom fil } \\
19 \\
\text { to } \\
21\end{array}$ & $\begin{array}{c}\text { irst do } \\
22 \\
\text { to } \\
23\end{array}$ & $\begin{array}{c}\text { ose } \\
24 \\
\text { to } \\
25\end{array}$ & $\begin{array}{l}26 \\
t o \\
28\end{array}$ & $\begin{array}{c}29 \\
t o \\
30\end{array}$ & $\begin{array}{r}31 \\
\text { to } \\
32\end{array}$ & $\begin{array}{r}33 \\
\text { to } \\
35\end{array}$ & $\begin{array}{r}36 \\
\text { to } \\
37\end{array}$ & $\begin{array}{l}38 \\
\text { to } \\
39\end{array}$ \\
\hline $\begin{array}{c}\text { Busulphan } \\
10 \\
5\end{array}$ & $\begin{array}{l}106 \\
114\end{array}$ & $\begin{array}{l}69 \\
60\end{array}$ & $\begin{array}{r}9 \\
33\end{array}$ & $\begin{array}{l}13 \\
58\end{array}$ & $\begin{array}{l}53 \\
69\end{array}$ & $\begin{array}{l}75 \\
85\end{array}$ & $\begin{array}{l}125 \\
125\end{array}$ & $\begin{array}{r}80 \\
100\end{array}$ & $\begin{array}{l}74 \\
95\end{array}$ & $\begin{array}{l}77 \\
86\end{array}$ & $\begin{array}{l}22 \\
43\end{array}$ & $\begin{array}{r}0 \\
59\end{array}$ & $\begin{array}{r}8 \\
110\end{array}$ & $\begin{array}{r}31 \\
106\end{array}$ & $\begin{array}{l}41 \\
90\end{array}$ & $\begin{array}{l}47 \\
83\end{array}$ & $\begin{array}{r}47 \\
100\end{array}$ \\
\hline $\begin{array}{l}\text { Cyclohexane- } \\
\text { 1,4-diol } \\
\text { dimethane- } \\
\text { sulphonate } \\
30 \\
20\end{array}$ & $\begin{array}{r}78 \\
100\end{array}$ & $\begin{array}{l}94 \\
61\end{array}$ & $\begin{array}{l}11 \\
23\end{array}$ & $\begin{array}{l}27 \\
11\end{array}$ & $\begin{array}{l}60 \\
40\end{array}$ & $\begin{array}{l}75 \\
72\end{array}$ & $\begin{array}{r}76 \\
100\end{array}$ & $\begin{array}{r}117 \\
63\end{array}$ & $\begin{array}{l}35 \\
75\end{array}$ & $\begin{array}{r}8 \\
36\end{array}$ & $\begin{array}{r}0 \\
15\end{array}$ & $\begin{array}{l}0 \\
6\end{array}$ & $\begin{array}{r}0 \\
31\end{array}$ & $\begin{array}{r}0 \\
43\end{array}$ & $\begin{array}{l}11 \\
86\end{array}$ & $\begin{array}{l}32 \\
75\end{array}$ & $\begin{array}{l}25 \\
82\end{array}$ \\
\hline
\end{tabular}

* Five daily doses in each case, four birds per experiment. 
Both courses of cyclohexane-1,4-diol dimethanesulphonate induced a Myleran-type effect on quail fertility (Table 1). After the higher dose level $(5 \times 30 \mathrm{mg} / \mathrm{kg})$, the second phase of low fertility was associated with sterility between Days 24 and 32 . After the lower dose treatment, the antifertility action was again most marked between Days 26 and 28 from the first dose.

In the male rat, the sterilising effect of Myleran has been correlated with a selective lethal action on the spermatogonia (de Rooij \& Kramer, 1968; Kramer \& de Rooij, 1970). Over the dose range of 4 to $10 \mathrm{mg}$ Myleran $/ \mathrm{kg}$ (Jackson, Fox \& Craig, 1961), the duration of spermatogenesis was assessed to be between 9 and 10 weeks as judged by the onset of sterility with aspermia. A similar estimate was obtained in the rabbit on the basis of an acute phase of aspermia in Week 10 following a single dose of $40 \mathrm{mg}$ Myleran $/ \mathrm{kg}$ (Fox, Jackson, Craig \& Glover, 1963), and a later study in the rabbit using tritiated thymidine supported this view (Swierstra \& Foote, 1965). Despite the initial spermatogonial damage, the remaining spermatogenic cells continue to develop into spermatozoa, which accounts for the continuation of normal fertility until the supply of cells from these sources is exhausted.

Like the rabbit, mice tolerate much larger doses of Myleran (e.g. $40 \mathrm{mg} / \mathrm{kg}$ intraperitoneally) and the main antifertility effect resembles that seen in the rat (Jackson, 1966). A brief initial sterilizing effect was evident in the mouse after this dose. The onset of sterility in the 6 th week from treatment is also consistent with the estimate of 42 days for the duration of spermatogenesis from studies following radiation-induced damage or the use of tritiated thymidine (Oakberg, 1956).

In the rat and mouse, it was recently shown that cyclohexane-1,4-diol dimethanesulphonate produced a similar sterilizing effect to that of Myleran (Jackson, 1971). A brief inhibitory action on fertility occurred in both rats and mice during Week 2 from the given dose of this compound, followed by recovery and later onset of sterility in Weeks 6 and 8 in mice and rats, respectively.

The biphasic antifertility effect found in Japanese quail after both Myleran and the cyclohexane-1,4-diol dimethanesulphonate shows a consistent resemblance to that obtained in rodents, the major action of the compounds again being directed against the spermatogonia. Like the mouse, rabbit and guinea-pig, the Japanese quail is more resistant than the rat to these compounds. The present data provide an estimate of about 25 days for spermatogenesis and sperm transit time through the ductus deferens in Japanese quail. According to Mather \& Wilson (1964), mature spermatozoa are being produced by Japanese quail 36 days after hatching. Spermatogonia were first observed in this species about 11 days after hatching (Purcell, 1970). This information provides an alternative estimate of 25 days ( 36 minus 11 days), for the duration of spermatogenesis, which is in close agreement with the findings in the current work.

This work was carried out with the support of a grant from the Ford Foundation.

\section{REFERENCES}

DE RooIJ, D. G. \& Kramer, M. F. (1968) Spermatogonial stem cell renewal in the rat, mouse and golden hamster. A study with the alkylating agent Myleran. Z. Zellforsch. mikrosk. Anat. 92, 400 . 
Fox, B. W., Jackson, H., Graig, A. W. \& Glover, T. D. (1963) Effects of alkylating agents on spermatogenesis in the rabbit. F. Reprod. Fert. 5, 13.

JAckson, H. (1964) The effects of alkylating agents on fertility. Br. med. Bull. $20,107$.

JaCKson, H. (1966) Antifertility compounds in the male and female, p. 63. Thomas, Springfield, Illinois.

JACKson, H. (1971) Non-steroidal antifertility agents in the male. In: Control of Human Fertility. Nobel Symposium no. 15, p. 119. Eds. E. Diczfalusy and U. Borell. Almquist \& Wicksell, Stockholm.

Jackson, H., Fox, B. W. \& Craig, A. W. (1961) Antifertility substances and their assessment in the male rodent. F. Reprod. Fert. 2, 447.

Jones, P., Kominkova, E. \& JAckson, H. (1972) Effects of antifertility substances on male Japanese quail. F. Reprod. Fert. 29, 71.

Kramer, M. F. \& DE RoorJ, D. G. (1970) The effect of three alkylating agents on the seminiferous epithelium of rodents. II. Cytotoxic effect. Virchows Arch. Abt. B Zellpath. 4, 276.

Mather, F. B. \& Wilson, W. O. (1964) Post-natal testicular development in Japanese quail (Coturnix coturnix japonica). Poultry Sci. 43, 860.

OAKBerg, E. F. (1956) Duration of spermatogenesis in the mouse and timing of stages of the cycle of the seminiferous epithelium Am. 7. Anat. 99, 507.

Purcell, S. M., JR (1970) Morphological and stereological evaluation of the testes of the Japanese quail (Coturnix coturnix japonica). Diss. Abstr. (B), 31(5), 2427.

SwIERstra, E. E. \& Foote, R. H. (1965) Duration of spermatogenesis and spermatozoon transport in the rabbit based on cytological changes, DNA synthesis and labelling with tritiated thymidine. Am. F. Anat. 116, 401. 